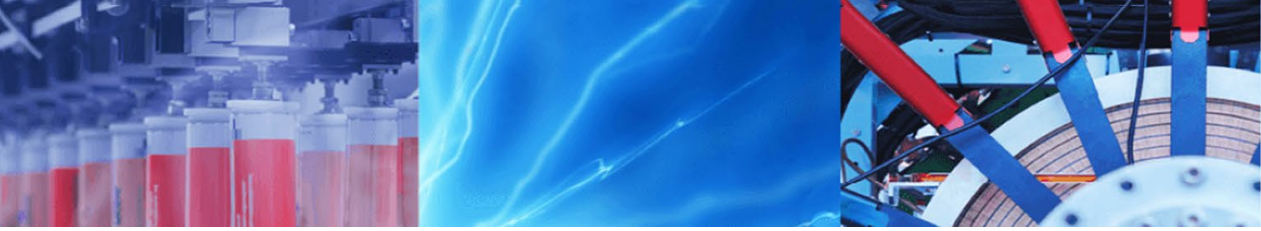

Research Article

\title{
Land use/cover mapping and assessing the impact of solid waste on water quality of Dal Lake catchment using remote sensing and GIS (Srinagar, India)
}

\author{
Junaid Qadir ${ }^{1}\left[\right.$ Perminder Singh ${ }^{2}$
}

(c) Springer Nature Switzerland AG 2018

\begin{abstract}
The current study was carried out to monitor the changing land use/cover and assess the impact of solid waste on water quality of Dal Lake in Srinagar city (India). Various data sets were used for analysis of geomorphology studies such as socio-economic changes and water quality status. The study reveals that agriculture land decreased from 13 to $11.39 \%$, forests from 2.55 to $1.41 \%$, water from 22.05 to $19.85 \%$, and plantation from 22.28 to $14.65 \%$. Although the study also reveals there has been an increase in built-up from 8.87 to $23.90 \%$, aquatic vegetation increased from 10.25 to $17.03 \%$. Finally, changes in all categories were correlated and it was found that the wards surrounding the Dal Lake show the dynamic change in land use/cover and solid waste parameters which in turn changed the water quality of Dal Lake. It was observed that solid waste generated varies from ward to ward depending upon land use cover and socio-economics. In order to protect the lake basin, controlled human activities, land use and water resources within the catchments are to be done in cooperation between the government departments, local authorities and the general local community around Dal Lake catchment.
\end{abstract}

Keywords Dal Lake $\cdot$ Ecosystem $\cdot$ Land use land cover $\cdot$ Socio-economics $\cdot$ Solid waste

\section{Introduction}

Land use/cover change has become a dominant component in current policies for managing natural resources and monitoring environmental changes from local to national and to global scales. The current shifting situation in the land use and land cover due to the variety of factors such as climate, physical and socio-economic changes is directly interfering in the socio-economic status of local people. The rate of change and the nature of transition can differ in time and space. Some regions tend to appear stable, whereas other areas are subjected to rapid and persistent transformation due to accelerated human interferences with the environment. With the rapid increase in the population in developing countries like India, focus on smart cities and tourism development activities has grown immensely, which ultimately had led to a change in the existing state of land use and land cover topographies $[11,23,33]$. For this purpose, change detection analysis (decadal) for land use and land cover can be performed on a temporal scale to better understand the shifting trend causing due to accelerated anthropogenic activities [7]. In order to improve the worsening bio-environmental conditions, it is necessary to use every bit of land in a balanced way. This requires to fully understand past and present conditions of that area. Perhaps land use/cover dynamics are widespread and are significantly driven by human activities that eventually produce changes that impact human lives [23]. Remote sensing helps in the field of land use/cover mapping and their change detection. One of

\footnotetext{
$\triangle$ Junaid Qadir, qadirjunaid10@gmail.com | ${ }^{1}$ Department of Geography and Regional Development, University of Kashmir, Srinagar 190006, India. ${ }^{2}$ Centre for Climate Change and Mountain Agriculture, Sher-e-Kashmir University of Agricultural Sciences and Technology (SKUAST-K), Srinagar 190025, India.
}

SN Applied Sciences (2019) 1:25 | https://doi.org/10.1007/s42452-018-0027-6

Received: 27 August 2018 / Accepted: 16 October 2018 / Published online: 29 October 2018 
the major advantages of remote sensing systems is their capability for repetitive coverage, which is necessary for change detection studies at global and regional scales. Land use/cover change is critically linked to natural and human influences on the environment. The advancement in remote sensing and geographic information science offers a promising framework to monitor land changes [30]. Given the wide range availability of time series satellite data, Landsat data have been predominantly used in land use/cover classification and change detection (e.g. $[10,16,20,25])$. It is important to mention here land use/ cover change detection basically uses one of the two different approaches for comparison analysis [21]. Two or more classified images of two different time periods [28] were compared pixel to pixel, and post-classification is considered to be the most appropriate and commonly used approach for change detection [15]. A variety of change detection techniques and algorithms have been developed and reviewed for their advantages and disadvantages. Among these unsupervised classifications or clustering, supervised classification, PCA, hybrid classification and fuzzy classification are the most commonly applied techniques used in classification (e.g. [18, 19, 24, 26, 34]).

Due to anthropogenic activities, the earth's surface is being significantly altered in some manner and man's presence on the earth's surface and his use of land has had a profound effect on the natural environment, thus resulting in an observable pattern in the land use/cover over time [9]. Direct dumping of the waste without proper examination and separation leaves a serious impact of environmental pollution causing a tremendous growth in healthrelated problems. Domestic, industrial and other wastes, whether they are of low- or medium-level wastes, are causing environmental pollution and have become perennial problems for mankind [27]. If this situation is not handled in a proper manner within time, then it would lead to the worst-case scenario on a global scale. This study is important because Dal Lake is a favourite tourist destination and attracts thousands of tourists every year. Due to its tourism potential, it generates huge revenue and provides employment directly and indirectly to the residents living there. The Dal Lake is also one of the very few water bodies in the world having permanent human settlements within its confines. Many aquatic plants growing in the lake are used as food, fodder and compost for agriculture fields. The water of the lake is supplied for drinking and other domestic purposes. Dal Lake is subjected to accelerated degradation due to the variety of human activities including indiscriminate disposal of liquid and solid waste by population residing in and around Dal Lake. The main objective of the present research was to utilize GIS and remote sensing technology to discern the extent of changes that occurred in Dal Lake catchment in Srinagar, Jammu and Kashmir, over 30-year time period. However, the specific objectives included (1) to identify and delineate different land use/cover categories and pattern of land use change around Dal catchment from 1981 to 2011 (2) to assess the impact of solid waste on water quality.

\section{Study area}

The Dal Lake and its catchment are situated between the geographical coordinates of $34^{\circ} 02^{\prime}-34^{\circ} 13^{\prime} \mathrm{N}$ latitude and $74^{\circ} 50^{\prime}-75^{\circ} 09^{\prime} \mathrm{E}$ longitude. The location of the study area is shown in Fig. 1. Dal Lake commonly called as Heart of the Valley is surrounded on all sides by mountain ranges and occupies the central part of the Valley. City ward from the lake stands the Shankaracharya hill to the left and the Hari Parbat fort hill to the right. Towards the west are the snow-clad mountains of the Pir Panjal range (the remaining covered with snow from December to March or April), while on the eastern side are the extensions of Kailash Parbat. Dal Lake functions as the central part of a large interconnected aquatic ecosystem in Kashmir valley and is the major surface water body of the Valley. Dal Lake is a shallow, multibasin lake with an area of about $18 \mathrm{~km}^{2}$, out of which open water area is not more than $12 \mathrm{~km}^{2}$. It has both the inflow and the outflow water channels and is classified as a drainage lake [35] resembling more to a flow-through system rather than a quiescent water body. The catchment of the Dal Lake is not only highly diverse but also covers a huge area of $337 \mathrm{~km}^{2}$ which is nearly 18 times more than the lake area. It exhibits a varied topography with an altitudinal range of $1580-4360 \mathrm{~m}$. This area is surrounded by Sindh basin in the north and Jhelum basin in the south.

\section{Methodology and data sets}

Remote sensing and the GIS enable a varied way to classify the remote sensing data. With the advancement in the software part as well, statistical classifiers can also be used to classify remotely sensed data. In the present study, supervised classification technique (maximum likelihood algorithm) was used for classifying the Dal Lake and its surroundings. Different land use/cover classes such as agriculture, aquatic vegetation, bare land, built-up, grasslands, forests, horticulture, fallow land, plantation and water were categorized through the integration of remote sensing and GIS. The overall schematic plan of the methodology is given in Fig. 2. Satellite data from three different sensors, i.e. Landsat TM, ETM+ and IKONOS (Table 1), have been used in the present study as primary data sets. 


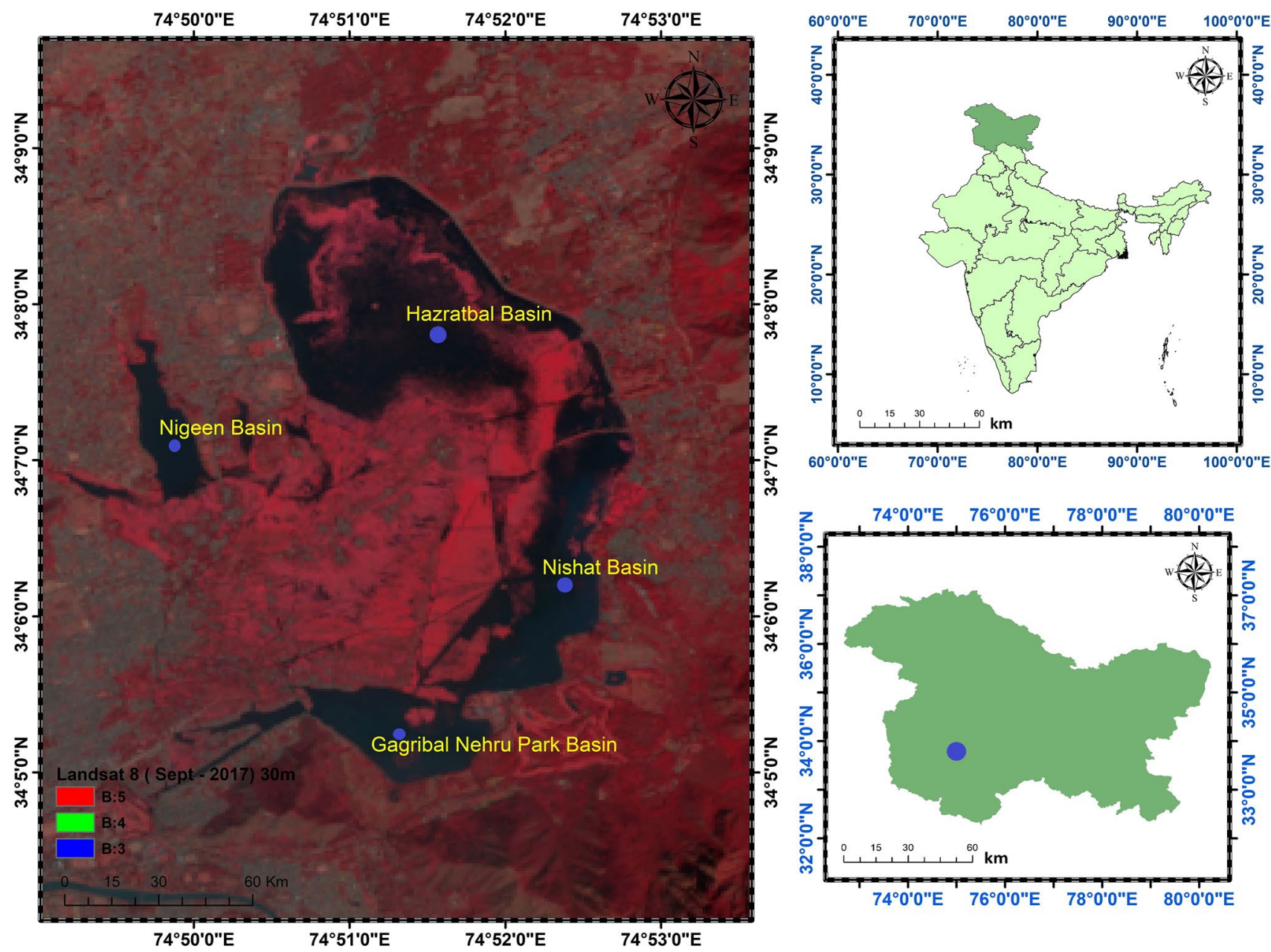

Fig. 1 Location map of the Dal Lake catchment, Srinagar (India)

Fig. 2 Methodology adopted for the study

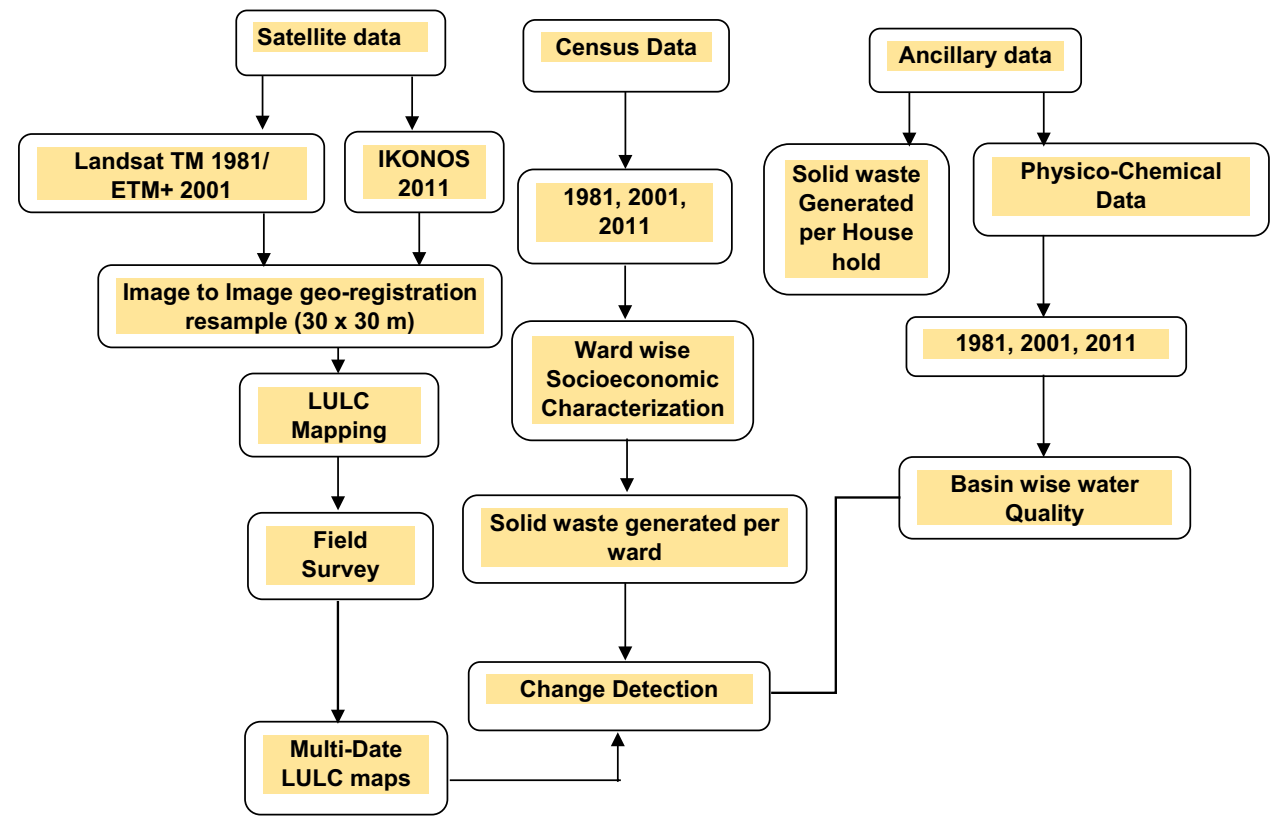

SN Applied Sciences 
Table 1 Sensor specification of Landsat TM, ETM+ and IKONOS

\begin{tabular}{|c|c|c|c|c|c|c|}
\hline \multirow{2}{*}{\multicolumn{2}{|c|}{$\begin{array}{l}\text { Landsat TM } \\
\text { Acquisition date: October } \\
1981\end{array}$}} & \multirow{2}{*}{\multicolumn{2}{|c|}{$\begin{array}{l}\text { ETM+ } \\
\text { Acquisition date: October } \\
2001\end{array}$}} & \multicolumn{3}{|l|}{ IKONOS } \\
\hline & & & & \multicolumn{3}{|c|}{ Acquisition date: October 2011} \\
\hline \multirow[t]{2}{*}{ Band $(\mu \mathrm{m})$} & \multirow[t]{2}{*}{ Resolution } & \multirow[t]{2}{*}{ Band $(\mu \mathrm{m})$} & \multirow[t]{2}{*}{ Resolution } & Band & $0.8 \mathrm{~m}$ PAN & $4 \mathrm{~m}$ MSS \\
\hline & & & & PAN & $450-900 \mathrm{~nm}$ & \\
\hline $0.433-0.453$ & $30 \mathrm{~m}$ & $0.433-0.453$ & $30 \mathrm{~m}$ & (Blue) & & $445-516 \mathrm{~nm}$ \\
\hline $0.450-0.515$ & $30 \mathrm{~m}$ & $0.450-0.515$ & $30 \mathrm{~m}$ & (Green) & & $506-595 \mathrm{~nm}$ \\
\hline $0.525-0.600$ & $30 \mathrm{~m}$ & $0.525-0.600$ & $30 \mathrm{~m}$ & (Red) & & $632-698 \mathrm{~nm}$ \\
\hline $0.630-0.680$ & $30 \mathrm{~m}$ & $0.630-0.680$ & $30 \mathrm{~m}$ & $(\mathrm{NIR})$ & & $757-853 \mathrm{~nm}$ \\
\hline $0.845-0.885$ & $30 \mathrm{~m}$ & $0.845-0.885$ & $30 \mathrm{~m}$ & & & \\
\hline $1.560-1.660$ & $60 \mathrm{~m}$ & $1.560-1.660$ & $60 \mathrm{~m}$ & & & \\
\hline \multirow[t]{2}{*}{$2.100-2.300$} & $30 \mathrm{~m}$ & $2.100-2.300$ & $30 \mathrm{~m}$ & & & \\
\hline & & $0.500-0.680$ & $15 \mathrm{~m}$ & & & \\
\hline
\end{tabular}

Table 2 Morphometric features of Dal Lake Basins [12]

\begin{tabular}{lllll}
\hline Basin characteristics & Nigeen & Gagribal & Hazratbal & Bod Dal \\
\hline Max. length $(\mathrm{km})$ & 2.5 & 1.5 & 3.2 & 4.6 \\
Max. width $(\mathrm{km})$ & 0.5 & 0.8 & 1.6 & 2.1 \\
Max. depth $(\mathrm{m})$ & 6.0 & 2.5 & 3.5 & 3.0 \\
Mean depth & 1.37 & 0.7 & 0.76 & 0.86 \\
Surface area $\left(\mathrm{km}^{2}\right)$ & 0.89 & 1.30 & 3.54 & 5.72 \\
Total volume $\left(\mathrm{mm}^{3}\right)$ & 1.22 & 0.93 & 2.76 & 4.92 \\
\hline
\end{tabular}

These data sets were downloaded from the Earth Explorer website (http://earthexplorer.usgs.gov/). It is important to mention here clear and cloud-free scenes were selected mainly for land use/cover mapping purposes because clouds screen study area and their shadows complicate the delineation [29]. The data sets used in the current study were geometrically corrected using Landsat ETM+ 2001 as a reference image. At least $40 \mathrm{GCPs}$ (ground control points) were used in rectification process to remove unsystematic errors that are commonly found in satellite data. The root mean square error (RMSE) varied from 0.20 to 0.40 pixels. Finally, a first-order polynomial was applied and all the available satellite data were resampled to $30 \mathrm{~m}$ pixel size using nearest neighbour method.

\section{Dal Lake basin}

The Dal Lake basin is a shallow, open drainage-type water body subdivided into five basins (including Brari Nambal basin). These basins differ markedly in their area, volume, maximum depth, mean depth, index of shoreline development and other characteristics [12] (Table 2). The largest one is the Bod Dal and the smallest one being the Brari Nambal. The basin walls are essentially convex towards the water, and index figures are less than unity [31]. The ratio between the mean and maximum depths ranges between 0.29 and 0.25 indicating a gentle slope of the lake bed (Fig. 3).

\subsection{Hazratbal basin}

This part is flanked by three Mughal Gardens-the Nishat, Shalimar and the Harwan on its eastern side and Hazratbal Mosque, University campus and Naseem Bagh on its western side. The Sona Lank, a small island, lies in this part of the lake. The maximum depth in this basin is $3.5 \mathrm{~m}$.

\subsection{Bod Dal basin}

It starts with Kotarkhana and Rupa Lank, and a small island is situated on it. On its eastern side lies Chashmashahi Bagh. It is $3 \mathrm{~m}$ in depth.

\subsection{Gagribal basin}

This part of the lake extends from Nehru Park to Kotarkhana. The Boulevard road constructed in 1930 has cut off a sizeable portion of the basin along the Shankaracharya hill. A number of hotels have been constructed along the roadside of the basin (maximum depth $2.5 \mathrm{~m}$ ).

\subsection{Nigeen basin}

This is the deepest of all the lake basins with a depth of $6 \mathrm{~m}$ and is mostly used for aquatic sports. 
Fig. 3 Evolution of Dal Lake (Source: Master Plan Srinagar city 1971)

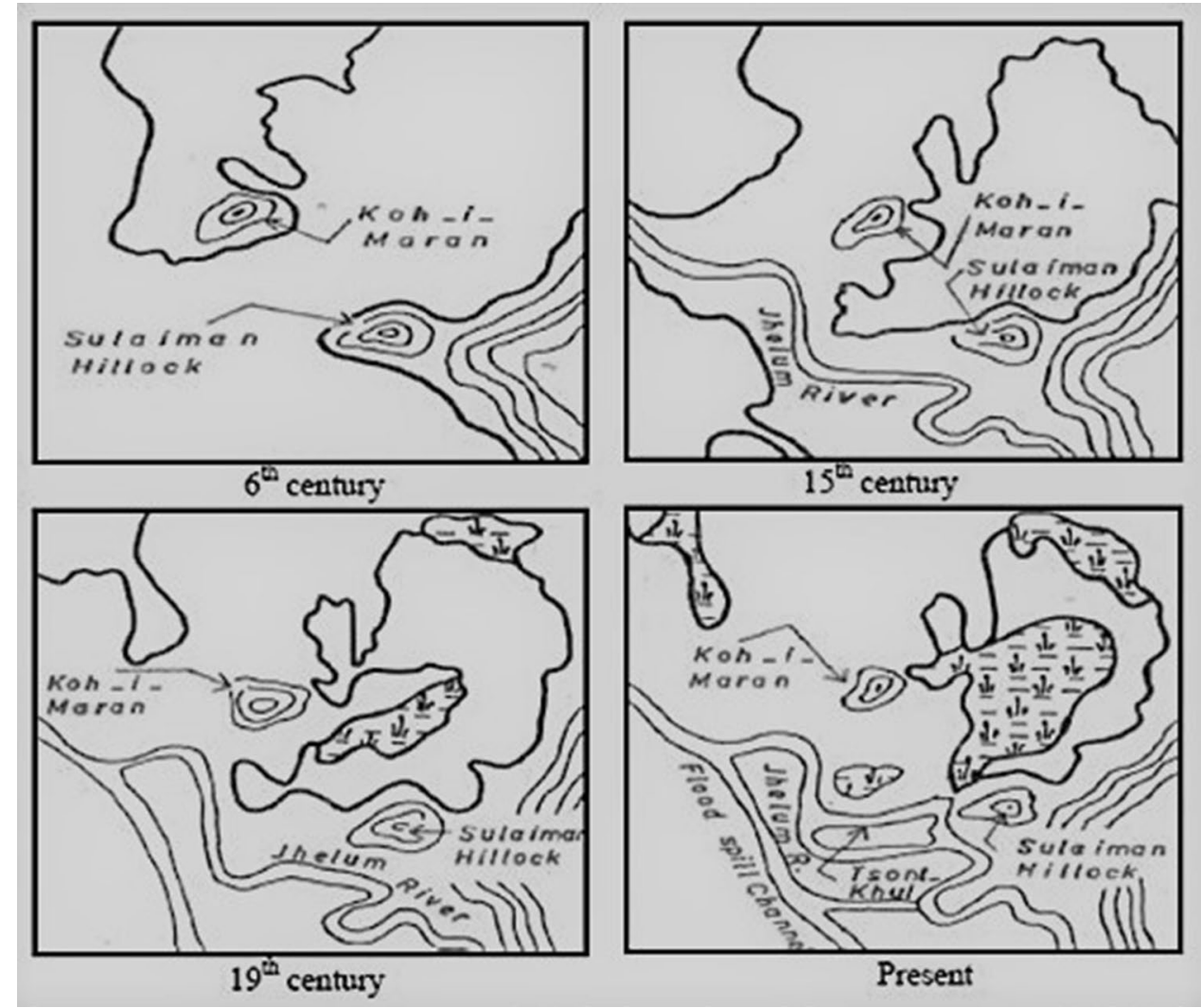

\section{Solid waste}

Solid waste refers to any unwanted material or garbage arising from domestic, commercial, agricultural, industrial activities or from other public entities. Though the description of the term will remain same at all times, it changes its features at different times. There is a large difference in solid waste from country to country. The type of solid waste primarily depends upon the commodity usage and lifestyle of people. Solid wastes are the wastes produced from human and animal activities that are usually solid and are mainly castoff as unwanted.

\subsection{Sources of waste}

\subsubsection{Municipal wastes}

Municipal wastes are composed of wastes generated by households and wastes of the similar character from shops, market and offices, open areas, and treatment plant sites (Table 3).

Table 3 Giving details about the source, facilities and type of waste

\begin{tabular}{|c|c|c|}
\hline Source & $\begin{array}{l}\text { Typical facilities, activities or locations where wastes } \\
\text { are generated }\end{array}$ & Types of solid waste \\
\hline Residential & $\begin{array}{l}\text { Single-family and multifamily dwellings, low-, } \\
\text { medium- and high-rise apartments, etc }\end{array}$ & Food wastes, rubbish, ashes, special wastes \\
\hline Commercial and institutional & $\begin{array}{l}\text { Stores, restaurants, markets, office, buildings, hotels, } \\
\text { motels, schools, print shops, auto repair shops, } \\
\text { medical facilities and institutions }\end{array}$ & $\begin{array}{l}\text { Food wastes, rubbish, ashes, demolition and } \\
\text { construction wastes, special wastes, occasionally } \\
\text { hazardous wastes }\end{array}$ \\
\hline Open areas & $\begin{array}{l}\text { Streets, alleys, parks, vacant lots, playgrounds, } \\
\text { beaches, highways, recreational areas, etc }\end{array}$ & $\begin{array}{l}\text { Street sweepings, roadside litter, rubbish and other } \\
\text { special wastes }\end{array}$ \\
\hline Treatment plant sites & $\begin{array}{l}\text { Water, sewage and industrial wastewater treatment } \\
\text { processes }\end{array}$ & Treatment plant sludge \\
\hline
\end{tabular}




\subsubsection{Industrial wastes}

Industrial process wastes include a very wide range of materials, and the actual composition of industrial wastes in a country will depend on the nature of the industrial base. Wastes may occur as relatively pure substances or as complex mixtures of varying composition and in varying physicochemical states. Examples of the materials which may be found under this heading are general factory rubbish, organic wastes from food processing, acids, alkalis, metallic sludges and tarry residues. The most important feature of industrial wastes is that a significant proportion is regarded as hazardous or potentially toxic, thus requiring special handling, treatment and disposal.

\subsubsection{Agricultural wastes}

Agricultural wastes, which may include horticultural and forestry wastes, comprise crop residues, animal manure, diseased carcasses, unwanted agrochemicals and 'empty' containers. Their composition will depend on the system of agriculture. Estimates of agricultural waste arising are rare, but they are generally thought of as contributing a significant proportion of the total waste matter in the developed world. Since 1960, as a result of huge rises in productivity, there have been corresponding increases in the volumes of crop residues and animal manure requiring disposal. There is likely to be a significant increase in agricultural wastes globally if developing countries continue to intensify farming systems.

\section{Accuracy assessment}

Classification is not complete until its accuracy is assessed [14]. Accuracy assessment determines the quality of the map extracted from remotely sensed data $[2,6]$. The accuracy assessments were done using confusion or error matrix. A confusion matrix contains information about actual and predicted classifications done by a classification system. The pixel that has been categorized from the image was compared to the same site in the field. The result of an accuracy assessment typically provides the users with an overall accuracy of the map and the accuracy for each class in the map [22]. In addition, nonparametric kappa test was also performed to measure the extent of classification accuracy. Kappa is a measure of inter-rater reliability or agreement between agreement between categorical variables $\mathrm{X}$ and $\mathrm{Y}$. It is calculated by a formula

$K=P(A)-P(E) / 1-P(E)$

where $P(A)$ is the number of times the $k$ raters agree and $P(E)$ is the number of times the $k$ raters are expected to agree only by chance $[8,32]$. The value of the kappa coefficient lies between 0 and 1. A kappa of zero occurs when the agreement between classified data and verification data equals chance agreement [5]. On the other hand, 1 represents the complete agreement between the two data sets. The kappa coefficient was introduced to the remote sensing community in the early $1980 \mathrm{~s}[3,4]$ and has become a widely used measure for classification accuracy.

\section{Results and discussion}

\subsection{Land use/cover categories}

In the present study, one of the most popular supervised classification methods (maximum likelihood algorithm (MLC)) was applied to analyse the shifting land use pattern using multitemporal satellite data of Landsat TM, ETM+ and IKONOS, respectively. A standard approach was applied for classification of the satellite data using Erdas Imagine 14 software starting from the selection of the training sites, extraction of signatures from the image, ground verification was done for doubtful areas, and then finally, maximum likelihood classification (MLC) classification algorithm was applied. The study area has been divided into the different land use/cover classes (Table 4).

Table 4 Brief description of land use/cover category class

\begin{tabular}{ll}
\hline Land use/cover class & $\begin{array}{l}\text { Description } \\
\text { Agriculture }\end{array}$ \\
$\begin{array}{l}\text { These are the fallow croplands devoid of crops at the time when the imagery was taken. Horticulture which includes } \\
\text { orchards, citrus fruits, herbs and shrubs is included in the category of agricultural land use }\end{array}$ \\
$\begin{array}{l}\text { This category includes all the forest area where the canopy cover/crown density is more than 40\% } \\
\text { Built-up }\end{array}$ \\
$\begin{array}{l}\text { It is an area of human habitation developed due to non-agricultural use and that has a cover of buildings, transport } \\
\text { and communication, utilities in association with water, vegetation and vacant lands } \\
\text { This category comprises areas with surface water, either impounded in the form of ponds, lakes and reservoirs or } \\
\text { flowing as streams and rivers }\end{array}$ \\
$\begin{array}{l}\text { These are the areas found along the agricultural cropland and wetlands. This plantation is more prominent along the } \\
\text { banks of lake/rivers throughout its length }\end{array}$
\end{tabular}




\subsection{Land use/cover of Dal catchment year 1981}

Land use/land cover map of 1981 (Fig. 4) was represented by 11 classes, viz. forests, grasslands, plantation, agriculture, horticulture, fallow lands, aquatic vegetation, water, stream bed, bare lands, built-up, among which water, plantation, agriculture were the dominant land use classes almost throughout the Valley floor with an area of 116.68, 117.92, and 68.79 (ha) (Table 5), respectively. They comprised $22.05,22.20$, and $13 \%$ of the study area, respectively. Forest, horticulture and grasslands were the other major land cover classes of the study area.

\subsection{Land use/cover of Dal catchment year 2001}

Land use/land cover map of 2001 (Fig. 5) was represented by 11 classes, viz. forests, grasslands, plantation, agriculture, horticulture, fallow lands, aquatic vegetation, water, stream bed, bare lands, built-up, among which water, plantation, agriculture were the dominant land use classes almost throughout the Valley floor with an area of $113.83,101.89$ and 60.5 (ha) (Table 6), respectively. They
Table 5 Status of land use/cover of Dal Lake catchment in the year 1981

\begin{tabular}{lcl}
\hline Land use/cover category & Area (ha) & Percentage \\
\hline Agriculture & 68.79 & 13 \\
Aquatic vegetation & 54.26 & 10.25 \\
Bare land & 0.07 & 0.24 \\
Built-up & 46.94 & 8.87 \\
Fallow land & 8.26 & 1.56 \\
Forest cover & 13.52 & 2.55 \\
Grasslands & 23.16 & 4.37 \\
Horticulture & 76.08 & 14.38 \\
Plantation & 117.92 & 22.2 \\
Stream bed & 3.37 & 0.63 \\
Water & 116.68 & 22.05 \\
Total & 529.06 & 100 \\
\hline
\end{tabular}

comprised $21.49,19.24$ and $11.43 \%$ of the study area, respectively. Forest, horticulture, grasslands were the other major land cover classes of the study area.
Fig. 4 Land use/cover map of Dal Lake and its catchment

\section{Land use/cover Map of Dal Lake (1981)}

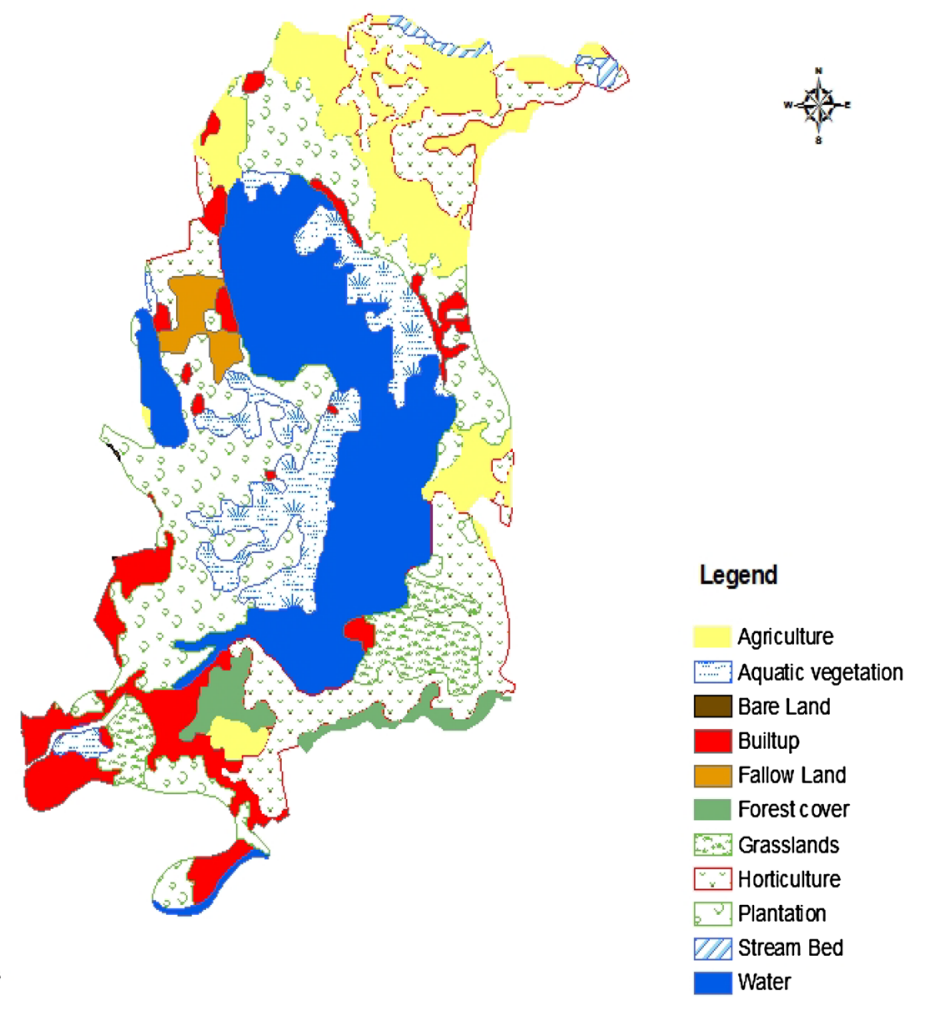


Fig. 5 Land use/cover Map of Dal Lake and its catchment

\section{Land use/cover Map of Dal Lake (2001)}

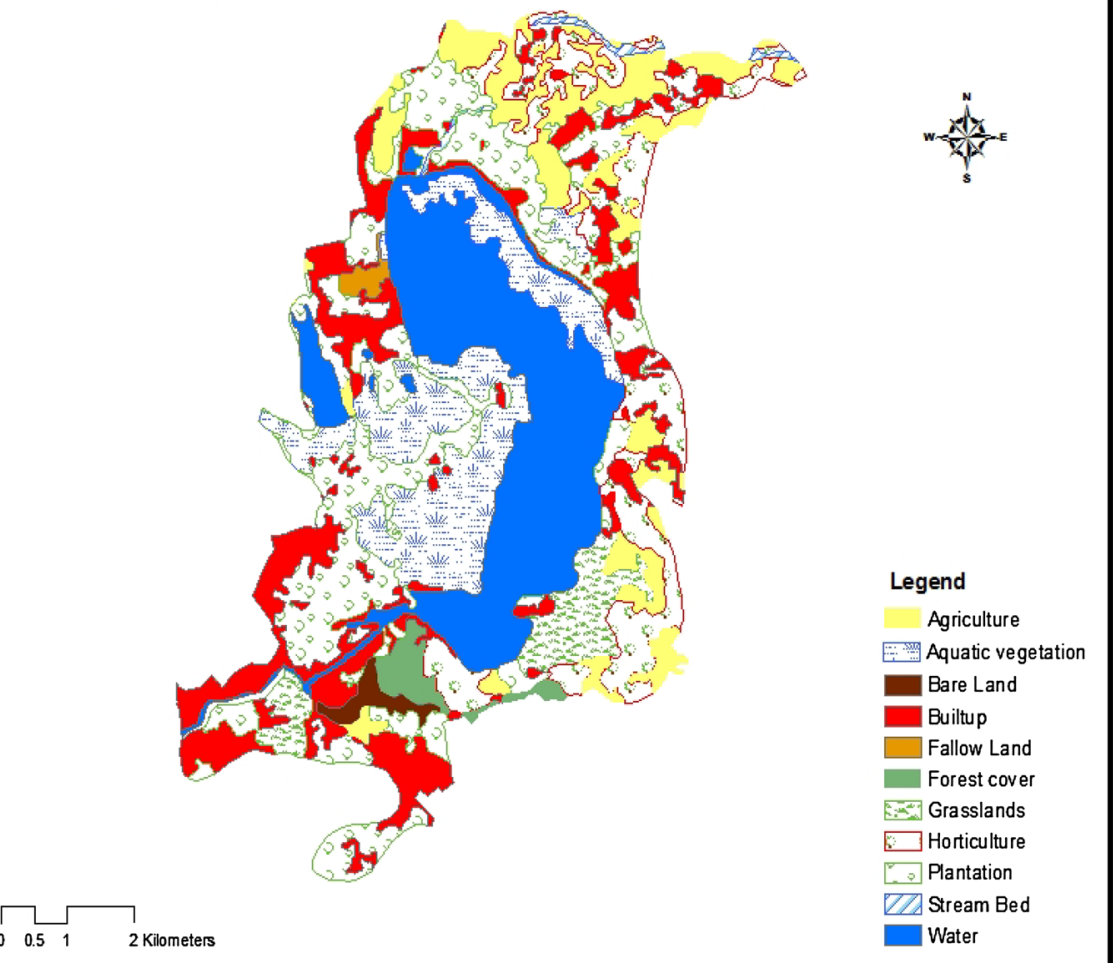

Table 6 Status of land use/cover of Dal Lake catchment in the year 2001

\begin{tabular}{lcl}
\hline Land use/cover category & Area (ha) & Percentage \\
\hline Agriculture & 60.5 & 11.43 \\
Aquatic vegetation & 74.54 & 14.07 \\
Bare land & 5.01 & 0.94 \\
Built-up & 84.09 & 15.87 \\
Fallow land & 2.68 & 0.50 \\
Forest cover & 8.34 & 1.57 \\
Grasslands & 22.01 & 4.156 \\
Horticulture & 52.98 & 10.00 \\
Plantation & 101.89 & 19.24 \\
Stream bed & 3.08 & 0.58 \\
Water & 113.83 & 21.49 \\
Total & 529.06 & 100 \\
\hline
\end{tabular}

\subsection{Land use/cover of Dal catchment year 2011}

Land use/land cover map of 2011 (Fig. 6) was represented by 11 classes, viz. forests, grasslands, plantation, agriculture, horticulture, fallow lands, aquatic vegetation, water, stream bed, bare lands, built-up. Aquatic vegetation and built-up show an increasing trend throughout the Dal Lake and are dominant land use classes with an area of 90.14, 126.47 (ha) (Table 7), respectively. It comprised 17.04, $23.91 \%$ of the study area, respectively. Forest, horticulture, grasslands were the other major land cover classes of the study area.

\subsection{Land use/cover change detection from the year 1981-2011}

Keeping the above in view, the change detection of Dal Lake catchment was done by using post-classification change detection method. The land use/land cover maps are prepared from two data sets Landsat TM (1981) and IKONOS (2011). By comparing the respective maps for 30 years, a general scenario of the major changes that have taken place in the catchment was derived. From Table 8, it is quite evident that the land use/cover pattern in the Dal Lake catchment has undergone considerable changes from 1981 and 2011. Aquatic vegetation has been the second dominant class after build-up and has shown a rise of $6.79 \%$, whereas build-up has shown a massive increase of $15.04 \%$. An error matrix was generated for different land use/cover classes using GPS 
Fig. 6 Land use/cover Map of Dal Lake and its catchment

\section{Land use/cover Map of Dal Lake (2011)}
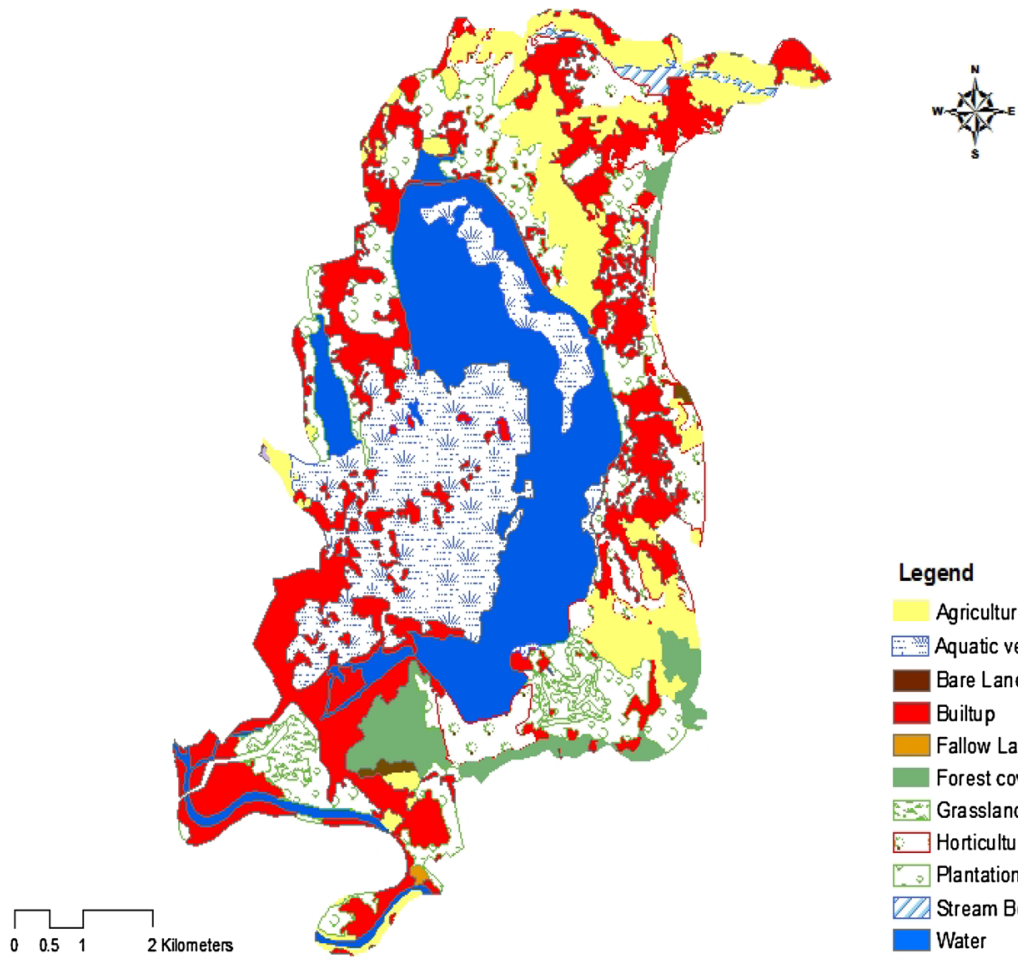

Legend

Agriculture

$\because$ Aquatic vegetation

Bare Land

Builtup

Fallow Land

Forest cove

Grasslands

2 Horticulture

P. Plantation

ZDS Stream Bed

Water
Table 7 Status of land use/cover of Dal Lake catchment in the year 2011

\begin{tabular}{lcl}
\hline Land use/cover category & Area (ha) & Percentage \\
\hline Agriculture & 60.29 & 11.40 \\
Aquatic vegetation & 90.14 & 17.04 \\
Bare land & 1.60 & 0.30 \\
Built-up & 126.47 & 23.91 \\
Fallow land & 0.44 & 0.08 \\
Forest cover & 7.46 & 1.41 \\
Grasslands & 21.03 & 3.97 \\
Horticulture & 34.31 & 6.49 \\
Plantation & 77.55 & 14.66 \\
Stream bed & 3.78 & 0.71 \\
Water & 105.99 & 20.03 \\
Total & 529.06 & 100 \\
\hline
\end{tabular}

surveying as a reference map for accuracy assessment. For this purpose, error matrix was generated for classes: agriculture, aquatic vegetation, built-up, horticulture, plantation, bare land, water, fallow land and grasslands,
Table 8 Area (ha) for change in different land use/cover classes

\begin{tabular}{llrrrc}
\hline S. no & Class name & \multicolumn{2}{c}{ Area (ha) } & \multirow{2}{*}{ Area change } & \% Change \\
\cline { 3 - 4 } & & 1981 & 2011 & & \\
\hline 1 & Agriculture & 68.79 & 60.29 & -8.50 & -1.6 \\
2 & Aquatic vegeta- & 54.26 & 90.15 & 35.88 & 6.79 \\
& tion & & & & \\
3 & Bare land & 0.07 & 1.60 & 1.53 & 0.06 \\
4 & Built-up & 46.94 & 126.47 & 79.54 & 15.04 \\
5 & Fellow land & 8.26 & 0.44 & -7.83 & -1.48 \\
6 & Forest cover & 13.52 & 7.46 & -6.06 & -1.14 \\
7 & Grasslands & 23.16 & 21.03 & -2.13 & -0.4 \\
8 & Horticulture & 76.08 & 34.31 & -41.77 & -7.89 \\
9 & Plantation & 117.92 & 77.55 & -40.38 & -7.54 \\
10 & Stream beds & 3.37 & 3.78 & 0.41 & 0.08 \\
11 & Water & 116.68 & 105.05 & -10.70 & -2.02 \\
Total & & 529.06 & 529.06 & & \\
\hline
\end{tabular}

and about 122 reference points were used to estimate overall accuracy (Table 9). With an overall accuracy of $90.98 \%$, kappa statistics were 0.90 and 0.89 , respectively, 
Table 9 Error matrix of LULC classification

\begin{tabular}{|c|c|c|c|c|c|c|c|c|c|c|c|}
\hline Class & Built-up & Agriculture & Horticulture & Plantation & Water & $\begin{array}{l}\text { Aquatic } \\
\text { vegeta- } \\
\text { tion }\end{array}$ & Grassland & Fallow & Bare land & Total & $\begin{array}{l}\text { Pro- } \\
\text { ducer's } \\
\text { accuracy }\end{array}$ \\
\hline Built-up & 71 & 0 & 0 & 1 & 0 & 0 & 0 & 0 & 1 & 73 & 97.26 \\
\hline Agriculture & 2 & 5 & 0 & 0 & 0 & 0 & 0 & 0 & 0 & 7 & 71.42 \\
\hline Horticulture & 0 & 0 & 2 & 0 & 0 & 0 & 0 & 0 & 0 & 2 & 100 \\
\hline Plantation & 1 & 0 & 2 & 15 & 0 & 0 & 1 & 1 & 0 & 20 & 75 \\
\hline Water & 0 & 0 & 0 & 0 & 2 & 0 & 0 & 0 & 0 & 2 & 100 \\
\hline Aquatic vegetation & 0 & 0 & 0 & 0 & 0 & 5 & 0 & 0 & 0 & 5 & 100 \\
\hline Grassland & 0 & 0 & 0 & 1 & 0 & 0 & 5 & 0 & 0 & 6 & 83.33 \\
\hline Fallow & 1 & 0 & 0 & 0 & 0 & 0 & 0 & 4 & 0 & 5 & 80 \\
\hline Bare land & 0 & 0 & 0 & 0 & 0 & 0 & 0 & 0 & 2 & 2 & 100 \\
\hline Total & 75 & 5 & 4 & 17 & 2 & 5 & 6 & 5 & 3 & 122 & \\
\hline User's accuracy & 94.67 & 100 & 50 & 88.24 & 100 & 100 & 83.33 & 80 & 66.67 & & \\
\hline
\end{tabular}

for the classification of 1981 and 2011 images. According to [13], accuracy assessment reporting requires the overall classification accuracy above $90 \%$ and kappa statistics above 0.9 which were successfully achieved in the present research.

\section{Social economic analysis around Dal Lake catchment from 1981 to 2011}

Our ability to anticipate future land use changes is severely limited by a lack of understanding of how socio-economics distribution affects the land use/cover. However, we explored to what socio-economic distribution can shift land use/cover system on a different trajectory. Dal Lake a cradle of Kashmiri civilization has a strong linkage with socio-economics of the state of J\&K. During the last few decades, an anthropogenic pressure in Dal Lake and its catchment have caused environmental deterioration. There is a rapid increase in the population residing in Dal Lake during the last 4 decades (Table 10). This increase has had its impact on farmland, wildlife habitat, grasslands, lake ecosystem and especially on the tourism industry.

\subsection{Generation of solid waste}

Waste generation is generally estimated on the basis of data gathered by conducting a waste characterization or using previous data on the waste generation available or combination of two approaches. Solid waste was generated by determining the total number of houses and the population residing in the study area. From the SMC (Srinagar Municipal Corporation data), it was observed that $1.5 \mathrm{~kg}$ of solid waste is generated per household (Fig. 7).

Table 10 Socio-economic data from 1981 to 2011 (Source: J\&K Census)

\begin{tabular}{|c|c|c|c|c|c|c|}
\hline \multirow[t]{2}{*}{ Ward name } & \multicolumn{2}{|l|}{1981} & \multicolumn{2}{|l|}{2001} & \multicolumn{2}{|l|}{2011} \\
\hline & Population & Household & Population & Household & Population & Household \\
\hline Harwan, Nishat & 23,978 & 3416 & 40,632 & 6009 & 49,721 & 7992 \\
\hline Dalgate, Lal Chowk & 20,906 & 3258 & 24,067 & 3427 & 31,425 & 3511 \\
\hline Bud Dal, Locut Dal & 12,928 & 1896 & 17,755 & 2027 & 32,328 & 5603 \\
\hline Jogi Lankar, Zindshah Sahib & 13,960 & 1947 & 41,715 & 6398 & 34,370 & 4777 \\
\hline Ganpatyar, Barbar Shah & 30,613 & 7413 & 50,293 & 7159 & 53,099 & 8382 \\
\hline Hazratbal, Tailbal & 14,917 & 1958 & 38,432 & 4252 & 36,902 & 5668 \\
\hline NIGEEN & 604 & 88 & 17,755 & 2027 & 26,934 & 2997 \\
\hline
\end{tabular}



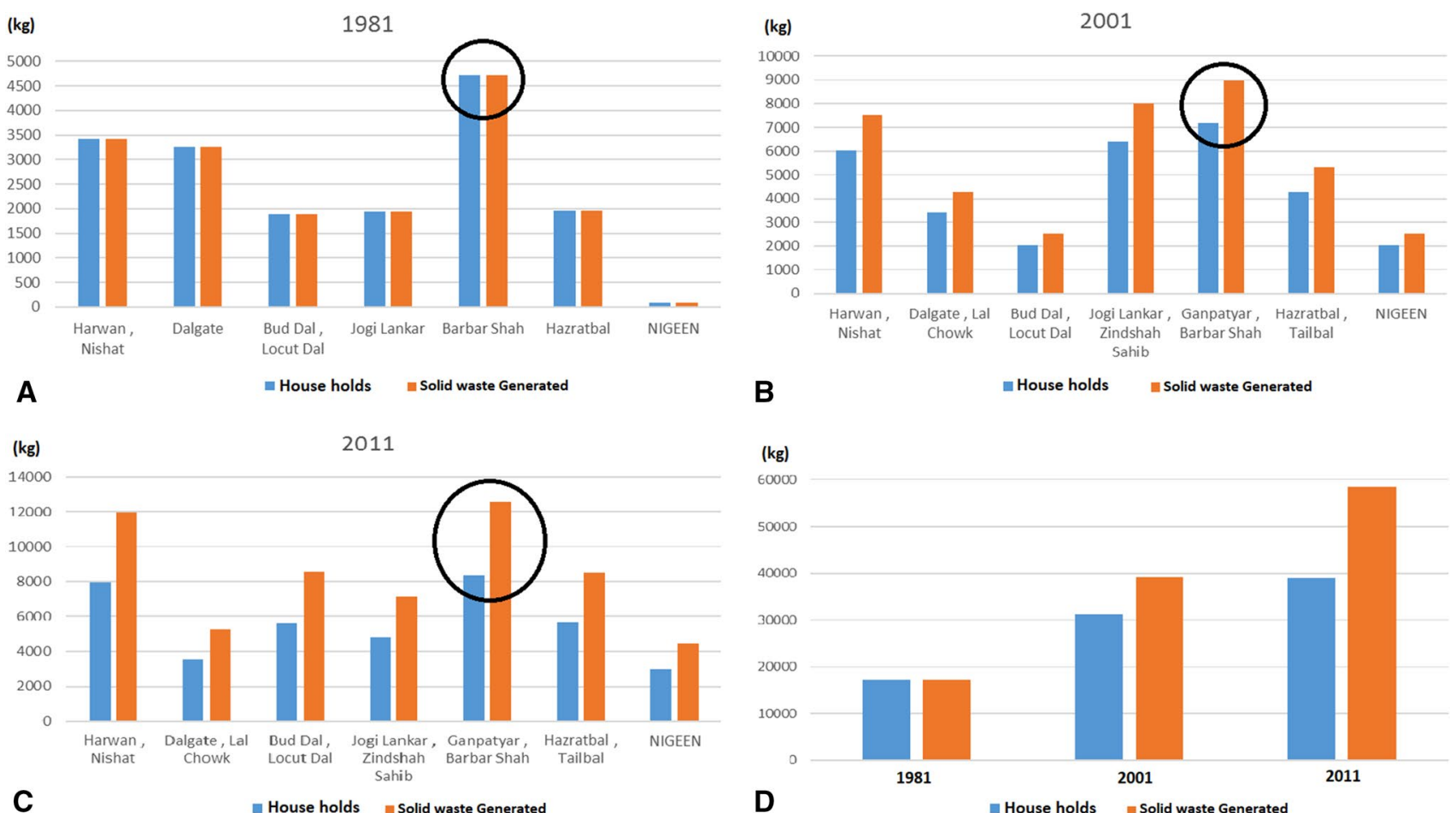

B

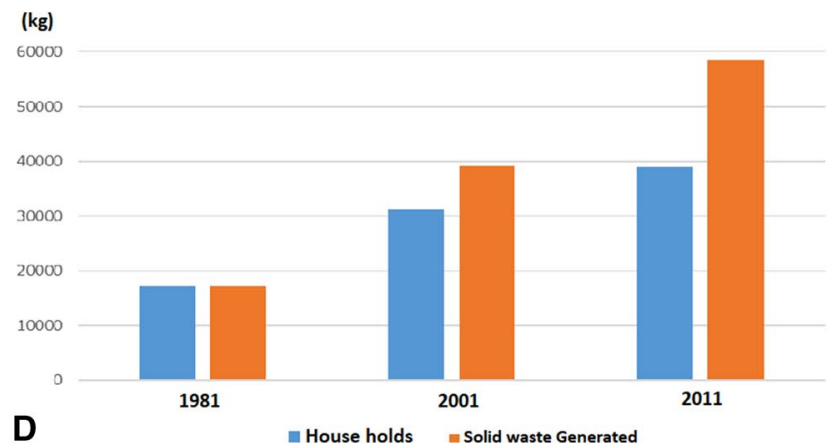

Fig. 7 Number of household and solid waste statistics wardwise for the a year 1981, b year 2001, c 2011, d overall from the year 1981-2011

\subsection{Water quality status of Dal Lake catchment}

When trying to manage a resource in the face of uncertainties, it is important to assess the seriousness and type of the assumed problem and must be seen in the overall framework of global sustainable development and towards inclusive ethics of using georesources responsibly $[1,17]$. Water resources all over the world are subjected to increasing pressure in terms of both quantity and quality [1]. Dal Lake catchment has been under tremendous anthropogenic pressure since more than three decades. There are countless ways in which people derive the livelihood from the lake, along with the numerous pollutant-generating activities that have stressed the lake ecosystem. These stresses have caused a significant damage to lake water quality. Excessive contributions of nutrients and organic matter, from the point and non-point sources, have led to eutrophication. Major shifts in oxygen regime from 1981 to 2011 have been recorded at Hazratbal basin (7.1-6.22 mg/l), Nishat basin (8.5-6.1 mg/l) and Nehru Park basin (7.5-5. $95 \mathrm{mg} / \mathrm{l})$, and these results indicate drastic changes in the water quality which can be attributed to an intensified release of nutrients due to runoff from immediate catchment, soil erosion, discharge of urban wastes including inorganic fertilizers (Table 11). The higher values of calcium are the clear indication of higher ingress of sewage into the lake, continued siltation, failure of retention of silt by partially commissioned settling basin and mineralization process of organic matter. The bacterial population has increased tremendously particularly in the houseboat areas and around Nishat, Boulevard and Gagribal due to an inadequate sanitary system, poor land practices around the Dal catchment and even inside floating vegetable gardens coupled with direct discharge of grey waters. Even some phytoplankters pollution indicator species, viz. Oscillatoria, Phacus, Microcystis, Cyclotella, Achnanthes, Euglena, Melosira and Nitzschia, are dominant, and a significant relationship has been recorded between the dominance of a particular algal class (Cyclops, Chydorus, Keratella, Brachionus) and the proximity of wastewater disposal sites in Dal Lake (Fig. 8). 


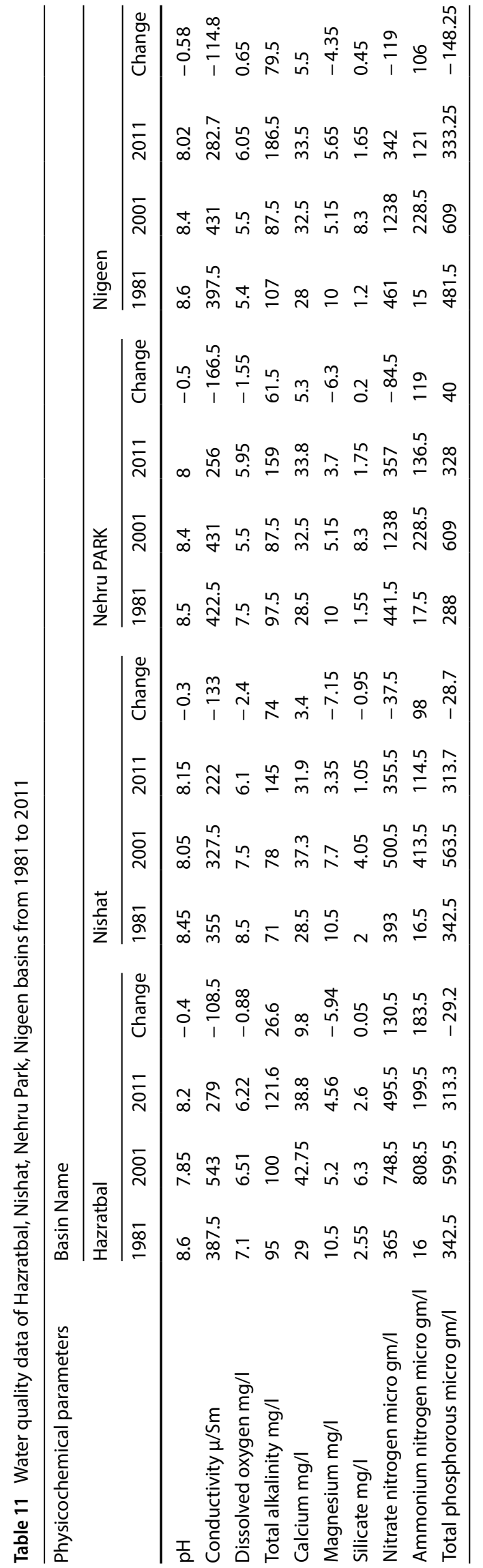

\section{Conclusions}

Analysis of the multitemporal satellite data of the year 1981, 2001 and 2011 discloses that there has been the rapid transformation of various landforms such as agricultural lands to residential class, water bodies into marshy and marshy into either residential or agriculture. The study reveals that the major land use in the Dal Lake catchment is built-up area. During the last 3 decades, the area under built-up has increased from 46.94 (ha) in 1981 to 79.54 (ha) in 2011 , whereas area under aquatic vegetation has shown a similar increasing status from 54.26 (ha) in 1981 to 90.15 (ha) in 2011. With the rapid increase in built-up and aquatic vegetation in and around the Dal Lake catchment has led to the fast deterioration of the lake ecosystem.

An increase in the human settlement within and around the Lake catchment has added rich solid waste, and direct discharge from the houseboats has added human waste to a point where health hazards are serious problems. Excessive contributions of nutrients and organic matter, from the point and non-point sources, have led to eutrophication. Major shifts in oxygen regime from 1981 to 2011 have been recorded at Hazratbal basin (7.1-6.22 mg/l), Nishat basin (8.5-6.1 mg/l) and Nehru Park basin (7.5-5. $95 \mathrm{mg} / \mathrm{l})$, and these results indicate drastic changes in the water quality. Untreated sewage and solid waste from the catchment areas directly into the Dal Lake has stressed the lake ecosystem in diverse ways and eventually led to a $70 \%$ decrease in water transparency.

The results of the current study have established that the Dal Lake represents a case of a threatened ecosystem in dire need of management with land use/cover changes, erosion, enhanced nutrient enrichment and rising human population in its catchment as the major threats to its existence. Land use and water quality are inseparable. Regulation of a proper land use plan in the Dal Lake catchment is vital for preventing the further nutrient enrichment and sedimentation of the lake waters. 

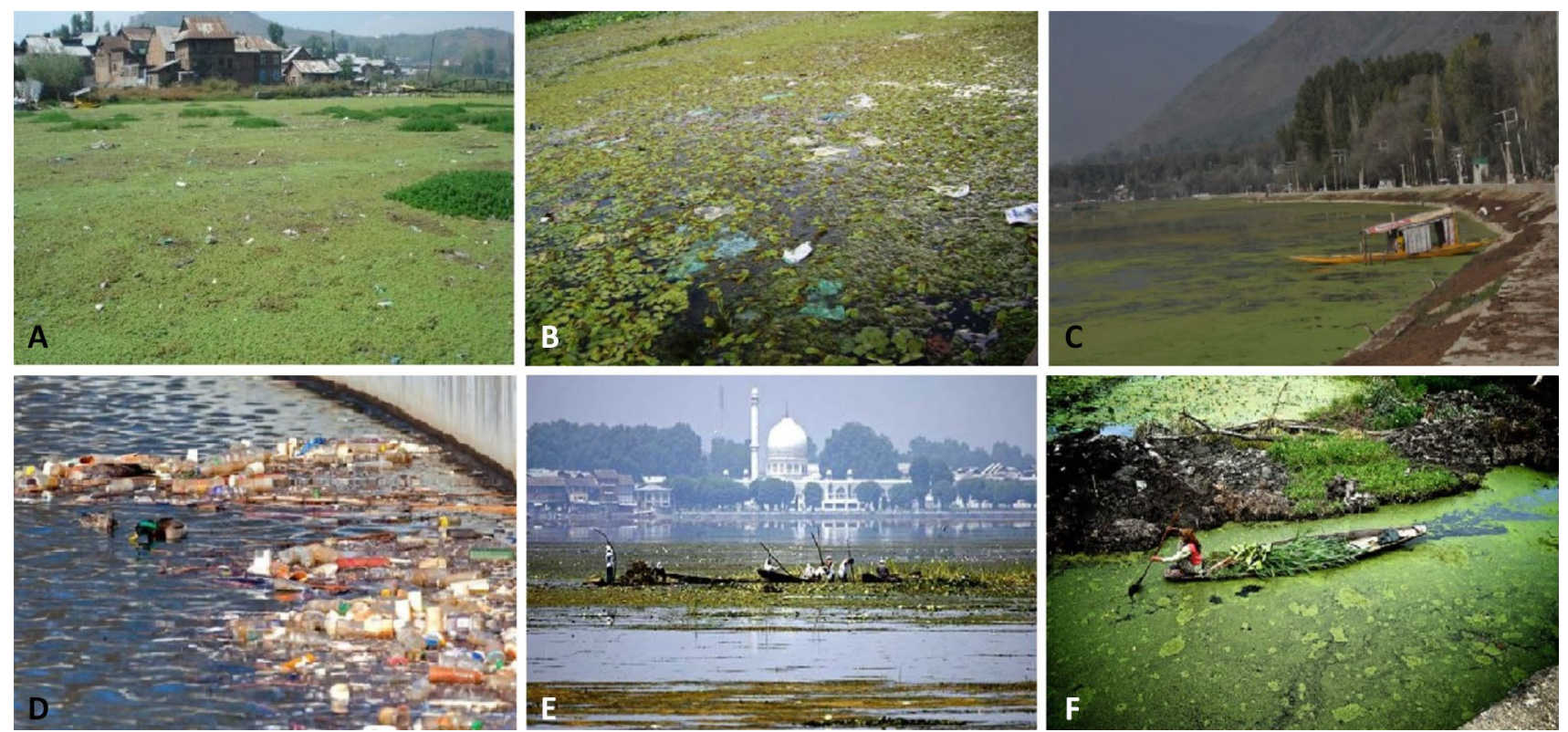

Fig. 8 Snapshots were taken during the field visit: a, b Nigeen Basin, c, d Nishat Basin, e, $\mathbf{f}$ Hazratbal Basin

Acknowledgements Authors would like to thank Srinagar Municipal Corporation (SMC), Lakes and water works Development Authority (LAWDA), J\&K Census Department for the data and suggestions, and also USGS (Earth Explorer) for downloading and accessing highresolution data.

\section{Compliance with ethical standards}

Conflict of interest On behalf of both authors, the corresponding author states that there is no conflict of interest.

Ethical standard This study is in full compliance with all applicable ethical standards.

Ethical approval This research paper does not contain any studies with human participants or animals performed by any of the authors.

Informed consent Each author contributed to the research in terms of conception, research design, cross-checking data analysis and cowriting the paper. Both authors read and approved the final manuscript.

\section{References}

1. Chaminé HI (2015) Water resources meet sustainability: new trends in environmental hydrogeology and groundwater engineering. Environ Earth Sci 73(6):2513-2520

2. Congalton RG, Green K (2009) Assessing the accuracy of remotely sensed data: principles and practices, 2 nd edn. CRC Press/Taylor and Francis, Boca Raton

3. Congalton R, Mead R (1983) A quantitative method to test for consistency and correctness of photointerpretation. Photogramm Eng Remote Sens 49(1):69-74
4. Congalton R, Oderwald R, Mead R (1983) Assessing landsat classification accuracy using discrete multivariate statistical techniques. Photogramm Eng Remote Sens 49(12):1671-1678

5. Fenstermaker L (1991) A proposed approach for national to global scale error assessments. In: Proceedings GIS/LIS'91, ASPRS, ACSM, AAG, AM/FM International and URISA, vol 1, pp 293-300

6. Foody GM (2002) Status of land cover classification accuracy assessment. Remote Sens Environ 80:185-201

7. Gibson P, Power C (2000) Introductory remote sensing: digital image processing and applications. Routledge, London

8. Gwet K (2002) Kappa statistic is not satisfactory for assessing the extent of agreement between raters. Stat Methods Inter Rater Reliab Assess 76:378-382

9. Iqbal M, Sajad H (2014) Watershed prioritization using morphometric and land use/land cover parameters of Dudhganga Catchment Kashmir Valley India using spatial technology. J Geophys Remote Sens 3:115

10. Jayappa KS, Mitra D, Mishra AK (2006) Coastal geomorphological and land-use and land-cover study of Sagar Island, Bay of Bengal (India) using remotely sensed data. Int J Remote Sens 27:3671-3682

11. Joshi RR, Warthe M, Dwivedi S, Vijay R, Chakrabarti T (2011) Monitoring changes in land use/cover of Yamuna riverbed in Delhi: a multitemporal analysis. Int J Remote Sens 32(24):9547-9558

12. Kaul V (1977) Limnological survey of Kashmir lakes with reference to tropic status and conservation. Int J Ecol Environ Sci $3: 29-44$

13. Lea C, Curtis AC (2010) Thematic accuracy assessment procedures: National Park Service Vegetation Inventory, version 2.0. Natural Resource Report NPS/2010/NRR-2010/204, National Park Service, Fort Collins, Colorado, USA

14. Lillesand TM, Kiefer RW (2000) Remote sensing and image interpretation, 4th edn. Wiley, New York

15. Lillesand TM, Kiefer RW, Chipman JW (2004) Remote sensing and image interpretation. Wiley, New York 
16. Liu H, Weng QH (2013) Landscape metrics for analysing urbanization-induced land use and land cover changes. Geocarto Int 28:1-12. https://doi.org/10.1080/10106049.2012.752530

17. Llamas MR (2004) Water and ethics: use of groundwater. UNESCO series on water and ethics, essay 7. UNESCO, New York

18. Lu D, Mausel P, Brondízio E, Moran E (2004) Change detection techniques. Int J Remote Sens 25(12):2365-2407. https://doi. org/10.1080/0143116031000139863

19. Lu D, Li L, Li G, Fan P, Ouyang Z, Moran E (2018) Examining spatial patterns of urban distribution and impacts of physical conditions on urbanization in coastal and inland metropoles. Remote Sens 10:1101

20. Mujabar PS, Chandrasekar N (2012) Dynamics of coastal landform features along the southern Tamil Nadu of India by using remote sensing and geographic information system. Geocarto Int 27(4):347-370

21. Mukherjee S, Shashtri S, Singh C, Srivastava P, Gupta M (2009) Effect of canal on land use/land cover using remote sensing and GIS. J Indian Soc Remote Sens 37:527-537

22. Pal S, Ziaul S (2017) Detection of land use and land cover change and land surface temperature in English Bazar urban centre. Egypt J Remote Sens Space Sci 20(1):125-145

23. Rawat JS, Biswas V, Kumar M (2013) Changes in land use/cover using geospatial techniques: a case study of Ramnagar town area. Egypt J Remote Sens Space Sci. https://doi.org/10.1016/j. ejrs.2013.04.002

24. Rundquist DC, Narumalani S, Narayanan RM (2001) A review of wetlands remote sensing and defining new considerations. Remote Sens Rev 20:207-226. https://doi.org/10.1080/02757 250109532435

25. Santhiya G, Lakshumanan C, Muthu kumar S (2010) Mapping of landuse/landcover changes of Chennai coast and issues related to coastal environment using remote sensing and GIS. Int J Geomat Geosci 1(3):563-576
26. Sariyilmaz FB, Musaoglu NM, Tanik A (2017) Investigation of land use/cover changes of Sazlidere basin by using band ratio for built-up area. Fresenius Environ Bull 26:39-45

27. Shaikh MA (2006) Using GIS in solid waste management planning. A case study of Aurangabad, India. Masters thesis submitted to IDA, Linköpings University 2006.

28. Shalaby A, Tateishi R (2007) Remote sensing and GIS for mapping and monitoring land cover and land-use changes in the Northwestern coastal zone of Egypt. Appl Geogr 27:28-41

29. Shukla A, Qadir J (2016) Differential response of glaciers with varying debris cover extent: evidence from changing glacier parameters. Int J Remote Sens 37:2453-2479. https://doi. org/10.1080/01431161.2016.1176272

30. Southworth J, Gibbes C (2010) Digital remote sensing within the field of land change science: past, present and future directions. Geogr Compass 4(12):1695-1712

31. Vass KK (1973) Studies on hydrobiology and primary productivity of some Kashmir Lakes. Ph.D. thesis, University of Kashmir, Srinagar

32. Viera AJ, Garrett JM (2005) Understanding inter-observer agreement: the kappa statistic. Fam Med 37:360-363

33. Yuan F, Sawaya KE, Loeffelholz BC, Bauer ME (2005) Land cover classification and change analysis of the twin cities (Minnesota) metropolitan area by multitemporal landsat remote sensing. Remote Sens Environ 98:317-328

34. Zhang S, Zhang S, Zhang J (2000) A study on wetland classification model of remote sensing in the Sangjiang plain. Chin Geogr Sci 10:68-73. https://doi.org/10.1007/s11769-000-0038-1

35. Zutshi DP, Khan MA 1978. On the Lake topology of Kashmir. Environmental physiology and ecology of plants. In: Singh, T. V. and Kaur, J., eds., Studies in the Eco-development of the Himalayas Mountain and Men. Lucknow, India, Print House. pp. 465-472. 